\title{
UMA LEITURA DO INDIVIDUALISMO, EM VIDAS SECAS, DE GRACILIANO RAMOS E SEARA VERMELHA, DE (JORGE AMADO)
}

\section{SILVA, Leila Barros dos Santos; OLIVEIRA, Humberto Luiz Lima de}

\author{
Bolsista Fapesb (Graduanda em Letras com Espanhol/UEFS) e-mail: \\ lbjpjleticia@hotmail.com.br \\ Orientador, Doutor em Literatura Comparada, ( Departamento De Letras E Artes,UEFS ), e-mail: \\ $\underline{\text { humbert_oliveira@uefs.br }}$
}

PALAVRAS-CHAVES: Representações, sociedade, literatura comparada, individualismo, exclusão social.

\section{INTRODUÇÃO}

Este trabalho faz parte do projeto de pesquisa: Assim caminha a Humanidade? Revisitando utopias; do individualismo, do coletivo e do comunitário e busca investigar as soluções narrativas apresentadas nas obras dos escritores Jorge Amado (Seara Vermelha) e Graciliano Ramos (Vidas secas), obras estas que mostram seres humanos esmagados pela crueldade de uma sociedade onde impera o individualismo. Assim, alguns personagens, presos no forte individualismo, sem capacidade de arregimentar forças para encontrar saídas, ignoram o poder do coletivo, e, assim, submetem-se aos grilhões do individualismo sob o domínio dos ricos fazendeiros e latifundiários que, com a febre do lucro condenam à exclusão as personagens representativas dos "condenados da terra" (negros, pardos e pobres) que povoam estas narrativas.

\section{MATÉRIAL E MÉTODO}

Para o andamento dessa pesquisa, inicialmente, foram empregadas técnicas de pesquisa qualitativa e bibliográfica com o objetivo de construir o conteúdo a ser analisado, para que assim possa haver a devida compreensão para a interpretação da problemática. Portanto, realizei leituras de obras literárias, para alcançar a finalidade desta proposta de trabalho.

\section{RESULTADOS PROPOSTOS/ALCANÇADOS}

Tomamos como base os métodos da Literatura comparada na medida em que 
esta plataforma conceitual permite estabelecer articulações entre obras e gêneros a partir de um fio condutor comum, no caso a temática, como nos lembra (MACHADO e PAGEAUX: 1989). Observe-se que Seara Vermelha, de Jorge Amado, e Vidas Secas, de Graciliano Ramos o tema principal, além do esmagamento das personagens pelo sistema de opressão, é a condição de pobres e migrantes, seres em exílio e em sofrimento ético-político. Em vidas secas(1963) Graciliano Ramos, discutiu a situação de miséria e exploração que o personagem Fabiano e sua família estavam submetidos. Sem laços de pertença ou solidariedade, Fabiano e sua família, isolados dos demais, não tinham como lutar contra a dominação (o soldado Amarelo, o Patrão) e a consequente exclusão social ( sem direitos sociais, o êxodo, a fuga, a fome, a ameaça da morte), apesar de Sinhá Vitória ter sonhos de uma vida melhor, como todos os outros pobres, não conseguem planejar um futuro diferente daquele de sofrimento e miséria social.

No romance seara vermelha, cuja ação se passa na caatinga, no Nordeste, também os "coronéis" expulsam os trabalhadores de suas casas, e, mesmo nascidos naquela mesma terra, são obrigados ao êxodo, à fuga, em busca de uma oportunidade de

trabalho. É este sonho de uma vida melhor que leva famílias inteiras a enfrentarem a dolorosa viagem tanto em terra quanto no mar. De fato, depois de vencerem as dificuldades de atravessarem a caatinga sob o sol inclemente da seca que assola a região, passando fome e sede, vendo morrerem pessoas da família e os animais de estimação, as personagens devem também resistir às ameaças que os desumanizam na própria vida social, ao chegarem em terra firme. Assim é que, vendendo seu corpo, Marta consegue um falso atestado médico para que o pai pudesse embarcar para São Paulo. A cidade de São Paulo, vista como a terra prometida, se torna um sonho impossível para a família de miseráveis que, pouco a pouco, vão ficando no caminho, vítimas do mais completo individualismo, sem conseguirem criar laços de solidariedade que canalizassem sua indignação e sua revolta contra as causas do seu sofrimento.

\section{CONSIDERAÇÕES FINAIS}

As soluções narrativas de cada romance, mesmo que se diferenciem, decorrentes que são de diferentes concepções de mundo dos escritores, apontam, ambas, para o peso esmagador do individualismo que leva homens e mulheres a padecerem de sofrimentos que poderiam ser 
evitados ou minimizados se outras fossem as formas de viver e pensar. De fato, tanto em Seara vermelha, quanto em vidas secas, o tema recorrente é a injustiça social, o desamparo dos trabalhadores rurais explorados por ricos proprietários. Assim, devido ao individualismo exacerbado dos proprietários da terra, as famílias são condenadas a viverem o drama da seca e da injustiça social, representadas na literatura.

\section{REFERÊNCIAS BIBLIOGRÁFICAS E OUTRAS}

AMADO, Jorge. Seara vermelha. Rio de Janeiro:Record,1987.

CARVALHAL, Tânia Franco. Literatura comparada. São Paulo: Editora Ática,1999

FANON, Frantz. Os condenados da terra. Rio de janeiro: Civilização Brasileira,1989.

FORGET, Danielle; OLIVEIRA, Humberto Luiz Lima de. Imagens do Outro: leituras divergentes da alteridade.Feira de Santana: UEFS,2001

HOLANDA, Francisco Uribam Xavier de. Do liberalismo ao neoliberalismo: o itinerario de uma cosmovisão impenitente. 2.ed - Porto Alegre: EDIPUCRS,2001.

NITRINI, Sandra. Literatura comparada: história, teoria e crítica. São Paulo: Editora da universidade de São Paulo,1997.

RAMOS, Graciliano. Vidas secas. São Pulo:Martins, 1968

SENNETT, Richard. O declínio do homem público: as tiranias da intimidade.

Disponível em:

<http://www2.fct.unesp.br/docentes/geo/eda/Pasta\%20de\%20textos\%20digitais\%20/O-

Declinio\%20do\%20homem\%20publico.pdf> Acesso em 05 de Abr 2018 